\title{
HOW TO PRICE IMPERFECT CERTIFICATION
}

\author{
Jan Mysliveček
}

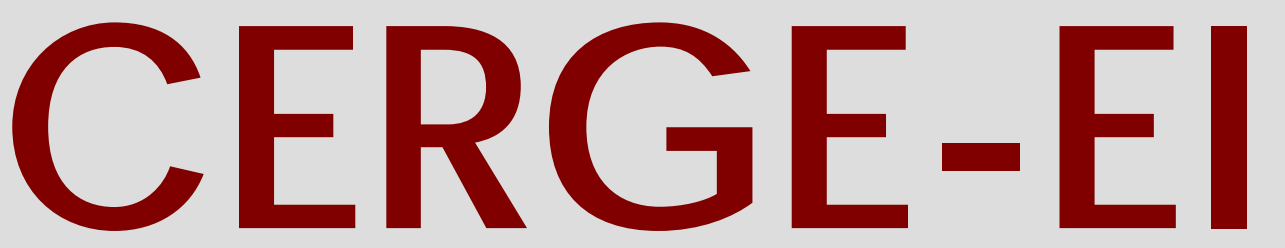

Charles University Centerfor Economic Research and Graduate Education Academy of Sciences of the Czech Republic Ec onomic s Institute 


\title{
Working Paper Series $\quad 364$ (ISSN 1211-3298)
}

\section{How to Price Imperfect Certification}

\author{
Jan Mysliveček
}

CERGE-EI

Prague, September 2008 
ISBN 978-80-7343-164-8 (Univerzita Karlova. Centrum pro ekonomický výzkum a doktorské studium)

ISBN 978-80-7344-153-1 (Národohospodářský ústav AV ČR, v.v.i.) 


\title{
How to Price Imperfect Certification Jan Mysliveček * CERGE-EI ${ }^{\dagger}$
}

\begin{abstract}
:
This paper analyzes markets in which consumers do not directly observe the quality of the products but form their expectations about the quality based on the outcome of voluntary imperfect certification. I analyze how the certification fee impacts the decisions of the producers to apply for a certificate and whether to supply goods of required quality. I find that there are both separating (only high quality producers apply and obtain the certificate) and pooling (both high and low-quality producers apply and obtain) equilibria. I show that the pooling equilibrium exists when the certification fee is low, while the separating equilibrium requires high certification fees. Since the pooling equilibrium is not welfare optimal, excessive competition between certifiers, which lowers the certification fee, is not beneficial. This result complements Strausz (2005) who shows that high certification fees are required to prevent the corruption of the certifier.
\end{abstract}

\begin{abstract}
Abstrakt:
Tento článek studuje trhy, na kterých spotřebitelé nevidí kvalitu výrobků, ale tvoří očekávání o kvalitě na základě výsledku dobrovolné certifikace. Studuji vliv poplatku za certifikaci na rozhodnutí výrobců o výrobě, přihlášení se do certifikačního programu a zda vyrábět požadovanou kvalitu. Výsledky ukazují, že existují obě rovnováhy - jedna, ve které se jen výrobci vysoké kvality přihlašují do certifikačního systému a druhá, ve které se i výrobci nízké kvality přihlašují. První z těchto rovnováh vyžaduje dostatečně vysoký certifikační poplatek. Protože druhá rovnováha není optimální, nadměrná konkurence snižující certifikační poplatek není prospěšná. Tento výsledek doplňuje článek Strausz (2005) ukazující, že vysoké poplatky jsou potřebné k tomu, aby zabránili korupci certifikátora.
\end{abstract}

Keywords: certification, imperfect testing, competition,adverse selection JEL Classification: D43, D45, D82

*I would like to thank Jung Hun Cho, Peter Katuščák, Andreas Ortmann, Joel Sobel and participants of the seminar at the University of California, San Diego for their comments. I'm in particular grateful to Andreas Ortmann for many discussions and suggestions that lead to the idea of this paper. The support of Grant Agency of Charles University No. 7743/2007 is gratefully acknowledged. This research was conducted during my stay at the University of California, San Diego, thanks to the support of the Fulbright Commission. The usual disclaimer applies.

${ }^{\dagger}$ CERGE-EI is a joint workplace of the Center for Economic Research and Graduate Education, Charles University, and the Economics Institute of Academy of Sciences of the Czech Republic. Address: CERGE-EI, PO Box 882, Politických vězno̊ 7, 11121 Prague, Czech Republic. Email: jan.myslivecek@cerge-ei.cz. 


\section{Introduction}

Certification systems are widely used to solve problems arising in situations of asymmetrical information. In particular, when consumers purchase a product infrequently or learning the quality is very costly, a certification system may lead to more efficient information transmission, because it replaces the need for individual consumer learning with a single certification test for producer. Typically, there is a single certifier, who tests all applying producers and assigns a single certificate to successful applicants (Lizzeri 1999). However, there are also several certification systems in which the owner of the certificate accredits several competing firms, who conduct the tests in his name (organic farming, the smog check of cars). It is not known, neither theoretically nor empirically, whether such competition merely reduces the price of certification or whether it also affects the quality of certificates and the distribution of applicants.

An example that motivates this research comes from the structure of organic farming certification. A producer may use the word "organic" (in the USA) or "BIO" (in the EU) on his product only if he obtains a certificate from an accredited certifier. Governments often accredit several firms (about two dozen in Germany and fifty-five in the USA). Even though certifiers may use their own label, I will later argue that it seems likely that consumers do not establish the reputation of individual certifiers because there is a large number of them, in contrast with a single, unified label "organic".

While this market structure creates new incentive problems regarding the necessary investment into the quality of testing, ${ }^{1}$ it is not clear that even reducing the certification fee is welfare improving for a fixed quality of testing. The reason for this somewhat surprising possibility is that the certification fee also helps separate high and low-quality producers. $^{2}$ To understand when lower certification fees benefit society, for example by

\footnotetext{
${ }^{1}$ If there are several certifiers among whom consumers do not distinguish, low-quality certification has negative externalities on other certifiers. This suggests that certifiers may lack sufficient incentives to carefully test applicants or to invest into testing technology, because they pay all the costs but benefit only partially due to the shared reputation with other certifiers.

${ }^{2}$ This results has been also shown by Svitkova and Ortmann (2006) in a somewhat different setting. They focus on how the choice of standards and fees by a certifier depends on its objective function when the distribution of quality of producers is fixed. This paper takes standards and fees as given and
} 
introducing more competition between certifiers, I study the effect these fees have on the entry decision of low and high-quality producers.

These results should serve as a caution to the regulators of existing certification systems. As these systems grow, the need for cheaper certification sometimes leads to calls for more competition between certifiers. The competition between certifiers may be useful in a number of circumstances, as it reduces monopoly rents that a single certifier is able to extract. However, excessive competition that reduces the price of certification may lead to the entry of low-quality producers and harm the trust of consumers in the certification systems. While price competition alone may result in the presence of lowquality producers among the certified, certifiers may even lower the quality of testing when competition intensifies, which would only strengthen these results. To prevent this, the regulator of such certification systems should accompany an increase in competition between certifiers by stricter supervision or by accreditation.

This paper complements Strausz (2005) who shows that the certification fee has to be high enough to discourage the certifier from accepting bribes from producers, using a repeat-purchase mechanism similar to Klein and Leffler (1981).

\section{Certification of organic products}

Organic food, believed by many to be healthier due to low or no content of pesticides, has witnessed significant growth in the recent years. As organic products became available in most supermarkets, the volume traded and the acreage of land producing organic products grew significantly. Total acreage quadrupled from 1995 to 2005 in the USA alone, from about 1 million acres to 4 million (USDA 2008e). The Organic Trade Association (2007) claims that average yearly growth over the past ten years reached almost $20 \%$ and the total volume of consumer sales reached $\$ 17.7$ billion. It estimates that organic sales account for about $2.8 \%$ of total food sales, with significantly faster focuses on how the choice of quality by producers depends on the quality of testing procedure and fee for certification. 
growth.

This success lead to some questions about the meaning of the "organic" label (New Yorker 2006). Both the European Union and the USA regulate organic production. They require that producers of organic products (farmers and processors) obtain a certificate before they label products as organic. ${ }^{3}$ Retailers who do not process the food do not need to be certified. Certificates can be obtained from accredited certifiers. Such accreditation is provided by the USDA or the national governments in the EU. There are currently 55 accredited certifiers in the USA. In the EU, each state accredits local certifiers, but their certificates have EU-wide validity. It is possible to find only public certifiers in certain member states and a number of competing private certifiers in others (European Commission 2005a). For example, Germany has currently 23 accredited private certifiers, while the Netherlands has just one public certifier.

The certification process is costly and long, especially for farmers. Any farm interested in producing organic products must enter a so-called transitional phase that lasts several years (USDA 2008d) during which the use of pesticides and other chemicals must fulfill organic label criteria, yet products cannot be yet sold as organic. Regulation requires at least one on-site inspection by a certifier every year, but also allows an unlimited number of additional visits in case the certifier considers such visits necessary or suspects any wrongdoing. Apart from certification costs, there are additional production costs related to organic food production. For example, organic farming is claimed to have a lower yield and to require more labor than traditional farming. On the other hand, there are subsidies for organic farmers that aim to partially offset these extra costs. Since the organic products are sold at significantly higher prices, these subsidies most likely do not fully cover these costs and "organic" production remains more expensive than the traditional production.

While the law specifies what is allowed in "organic" production and what is not, it

\footnotetext{
${ }^{3}$ In the USA, there are several categories with varying strictness (USDA 2008b). Labeling requirements differ based on the statements on the product. Requirements for retailers in the USA are explained in detaile in USDA (2008d).
} 
does not specify details of the certification in much detail. While regulation requires that certifiers collect any samples ${ }^{4}$ (water, soil, seeds, plants,...) necessary to ascertain that forbidden substances are not used on a farm applying for the organic certificate, it leaves the interpretation of this requirement to the certifiers. A modification of the current rules suggested by public interest groups to require at least $5 \%$ of unannounced visits every year was rejected by the USDA because "we [USDA] believe the certifying agent is in the best position to determine the need for additional on-site inspections" (USDA 2008a). Thus, the certifiers have a significant leeway in enforcing the standards.

Strict restrictions are also imposed on those who process food. Apart from the obvious requirements that all ingredients are organic, a complete separation of organic and non-organic production is often required. For example, grinding organic coffee requires a separate grinder used solely for that purpose.

Surprisingly little is known about the supervision of certifiers. Typically, governments list the requirements for the certifiers to become accredited and their initial evaluation. These requirements are education, experience and expertise, necessary knowledge, and technical equipment. Some governments also stipulate that certifiers cannot themselves be producers of organic food, nor can they certify producers living in the same city as themselves. While this somewhat limits the potential conflicts of interests, it is no panacea. It seems that the USDA relies on the complaints from the public to monitor the behavior of certifiers. However, complaints against farmers are referred to the certifiers and only complaints made against certifiers are dealt with by the USDA. Their website shows only one case of suspension or revocation of an accreditation of a certifier (USDA 2008c). ${ }^{5}$

Governments typically require that a name (USA) or a unique identifier (EU) of a

\footnotetext{
${ }^{4} \mathrm{~A}$ report by the European Commission (2005b) shows an interesting diversity in the number of samples collected. While in Belgium, the number of samples reaches $60 \%$ of the total number of certified "operators", there is a large number of EU members where the percentage is close to zero (about 1\%).

${ }^{5}$ There are no cases known to me in the European Union. However, this lack of evidence should not be construed as evidence of absence of such cases. Each member state accredits and monitors its own certifiers, which makes it difficult to verify the number of cases for all member states.
} 
certifier is present on most goods, exempting fruits and vegetables sold in bulk. This allows, at least in theory, each consumer to establish the reputation of each certifier. I argue that such an outcome seems unlikely for any significant portion of consumers, and I will assume in the model that all certifiers share only the label "organic". The justification for such an assumption comes primarily from the large number of certifiers that each consumer may be facing. Not only governments accredit several national certifiers, foreign certifiers are also often allowed to sell their products as organic. This increases the number of potential certifiers to several dozens. Moreover, consumers are often unable to evaluate the "organic" quality themselves without incurring significant costs. In the case of the whole "organic" market, consumers might form a reasonably precise estimate of quality of the organic testing based on word-of-mouth, consumers testing or governmental reports, which might guarantee sufficient flow of information. The information flow about each certifier may be smaller by an order of magnitude. Additionally, careful observation of all information about all relevant certifiers might be costly to the consumer. Even though I do not have any direct evidence to support the assumption that certifiers do not have a significant individual reputation, I will assume so for the sake of simplicity and clarity of the model and its results. If the certifiers would be able to establish they own reputation, the role of the reputation of the label "organic" would be weaker. Even though competition would still encourage entry of the low-quality producers, more of the reputation costs would be taken into account by each certifier, who would thus have bigger incentives to prevent the low-quality producer from getting the certificate.

\section{Literature review}

Certification as a solution to asymmetrical informations problems was offered as a potential remedy for Akerlof's (1970) "lemon" problem by Viscusi (1978). Further research focused mostly on models with perfect testing technology. 
Lizzeri (1999) explains a puzzle: Certifiers typically award a single certificate as a document of "passing" of the tests, even though they learn more information during the test, which they do not reveal. Lizzeri shows that awarding a single certificate to successful applicants is in fact a profit maximizing strategy of a certifier. He also shows that it is a unique strategy when the expected value of the product to the consumer is negative.

Biglaiser and Friedman (1994) show that middlemen, who purchase goods from various producers and sell them to consumers can in fact take the role of a certifier. The reputation building mechanism in this case is based on the loss on sales of other products. If a middleman attempts to cheat its consumers, he is punished by reduced sales on other products. This mechanism makes middlemen more trustworthy than a producer of one product line.

Strausz (2005) builds a model of certification, where individual producers have exogenously given quality, a certifier has perfect technology and upon testing, learns and reveals the true quality. Consumers are able to learn the quality after consumption. In such situation, a certifier is able to build its reputation, similarly as in Klein and Leffler (1981), if a certification fee is high enough to overcome the temptation to certify low-quality producers as being of high quality for a bribe. Strausz also shows that the honesty of a certifier can be assured at the lowest possible price only if the whole market is served by a unique certifier.

My model differs from Strausz' in several key aspects, but complements his results. While he focuses on the moral hazard problem of the certifier, I focus on the adverse selection of low-quality producers. Strausz studies the incentives of a certifier to resist the temptation of bribes; I study the impact of competition on the entry of high/lowquality producers. I will argue that even if the price is high enough to motivate certifiers to behave honestly, it may be too low to prevent the entry of low-quality producers. I assume that consumers cannot be cheated (in rational expectations equilibrium) because they correctly expect the probability that certified products are organic. I show that 
in the case of imperfect testing technology, low certification fees make the attempts to obtain a certificate by non-organic farmers more attractive, which reduces the quality of the certificate and welfare. Similarly to Strausz, I do not explicitly model the competition, but I formally model only the impact that lower fees and lower quality testing technology have on the long-run equilibria.

Thus, I show that lower certification fees, possibly as a result of competition between certifiers, are not beneficial because of the behavior of the producers. This is a complement to Strausz' results that low certification fees make honesty of the certifier less likely.

Little is known about what impact an imperfect testing technology has on market outcomes, with the notable exception of two studies.

Svitkova and Ortmann (2006) study the role of the objective function of the certifier, who can set the price of certification, its quality and required quality standards, to screen a fixed distribution of agents (charities in their case). In a situation where profitmaximizing certifiers set zero standards and extract rents without actually testing the applicants, not-for-profit certifiers choose positive standards, tests the applicants, and thus achieve a separation of high and low-quality charities, even though the separation is imperfect. Due to the complexity of such a model, their results are numerical. Even though our models are similar in spirit, I do not impose any objective function on the certifier, and I focus on the role of the certification fee and quality on testing on the participation decisions of the producers. In contrast to the analysis of not-for-profit charities, I focus on profit-maximizing producers. I also assume that consumers are heterogeneous, and quality can have only two levels (low and high).

A study by De and Nabar (1991) analyzes imperfect yet efficient testing technology, ie., the technology that makes high-quality producers more likely to pass the test. They assume that the certifier informs consumers also about producers who applied for but failed the test. This creates three categories of producers: those who applied and succeded, applied and failed, and did not apply at all. Because of these three categories, 
they do not find a separating equilibrium. In a separating equilibrium, only high-quality producers would apply for a certificate, and thus both "failed" and successfully certified producers would be able to sell their products for high prices equal to the valuation of a high-quality good. ${ }^{6}$ Any low-quality producers have the incentive to apply for certification because even failed application results in a high price of his good. Thus, there cannot be a separating equilibrium in such a model. In contrast, I assume that the certifier reveals only successful applicants. In such a market, the failed applicants sell in the market with producers who did not apply for a certificate. A separating equilibrium may exist if the probability of failure of the low-quality producer or the certification fee is sufficiently high.

The models also differ in additional assumptions and focus of the analysis. I assume heterogeneous consumers and endogenous entry both for high and low quality producers. Moreover, I assume that high-quality producers have positive production costs, while De and Nabar assume zero production costs for all producers. Finally, I assume an unlimited number of potentially low-quality producers applying for certification, while De and Nabar assume a fixed number and distribution of quality of producers.

Even though surprisingly little was published on the topic of competition between certifiers, there is some unpublished research available. A model of "Kosher Wars", certification of kosher food by Rabbis, is studied by Epstein and Gang (2002). Their model studies the choice of standards of certificates in a situation when consumers are able to distinguish between different certifiers (each has his own "label"). The authors find that increasing the number of congregations increases the standards. It is not clear that this is a result of competition because more congregations implies more certifiers as well as more potential consumers.

Finally, a paper by Franzoni (1998) studies Cournot like competition between certifiers with endogenous quality of testing technology. The author makes a few very significant assumptions that make the model easily tractable, yet somewhat unrealistic.

\footnotetext{
${ }^{6}$ Consumers are assumed to have rational expectations, and thus they would correctly expect both failed and successful producers to sell high-quality products.
} 
Most importantly, he assumes that the payoff to certified producers does not depend on the number of certified producers or even on the average quality of the certified products. This implies that consumers are systematically being fooled or are not behaving rationally. Even though there is an explicit form of supervision by government (in the form of imperfect liability of certifiers), certifiers are not interested in the quality of the label. In contrast, I believe that certifiers are somewhat motivated by the success of their certificates, yet when they share the certificate with competitors, these incentives may not be sufficient. I also focus on rational expectations equilibria, in which consumers expect average quality of certified products correctly. I do not model competition between certifiers explicitly and instead focus on the impact that certification fees have on the entry of low and high-quality producers.

\section{Model}

I present a simple model of certification, whose structure is motivated by the leading example of organic farming. I assume that there are two types of products - high (organic) and low (regular) quality. I assume that a linear demand exists for high quality products

$$
A-p
$$

where $A>0$ is a parameter. I will denote $s$ the probability that a certified producer is of high quality. If there is a measure $s_{h}$ of high quality producers and $s_{l}$ of low quality ones, then the probability that a certified producer is a high quality producer is

$$
s=\frac{s_{h}}{s_{l}+s_{h}}
$$


If consumers expect that the certified products are of high quality with probability $s \leq 1$, the derived demand function ${ }^{7}$ for certified products is

$$
A-\frac{p}{s}
$$

There is a measure $A$ of producers, who may produce high quality products with costs uniformly distributed over the range $[0, A]$. Moreover, I assume that the production costs of low-quality products are zero, and that there is an unlimited potential supply of low-quality producers. These assumptions are motivated by the co-existence of two markets: a smaller ${ }^{8}$ high quality market, where quality is costly to produce and a larger low-quality market. The high quality producers' costs thus represent additional production costs necessary to produce high quality products relative to the production costs of low-quality products, after possible subsidies are taken into account.

Consumers cannot observe whether a product is of high or low quality. Instead, they may rely on a certification system that allows producers to use the certificate (label "organic") on the products if they obtain a certificate. ${ }^{9}$ Obtaining a certification requires producers to undergo a noisy test that costs $f$. I begin with a symmetric testing technology that makes a mistake with probability $q<\frac{1}{2}$. This means that high-quality producers fail the test with probability $q$, and low-quality producers applying for the certificate will pass the test also with probability $q$. Later, I extend the analysis to allow asymmetric errors. The quality of testing technology, together with the number of high and low-quality producers applying for a certificate will determine the "quality" of a certificate, i.e., the probability $s$ that a certified product is in fact of high quality. I

\footnotetext{
${ }^{7}$ It is possible to derive a linear demand function from a uniform distribution of valuation over $[0, A]$. When consumers are risk neutral and expect that a certified products are organic with probability $s$ and of zero value with probability $1-s$, it is easy to show that the demand will be $A-\frac{p}{s}$.

${ }^{8} \mathrm{I}$ assume that even a high quality market is competitive, ie., each producer and consumer takes the price of the certified products as given. This seems reasonable in situations like organic farming, where thousands of farms are certified.

${ }^{9}$ I abstract from legal enforcement of such restrictions and simply assume that no producer uses the label without such a certificate. Even in a case where the owner of the label is not a government, there is usually a sufficient legal protection (trademarks, etc.) that prevents producers from mis-using the certificate.
} 
will focus on rational expectations equilibria in which consumers correctly expect this probability. All players are assumed to be risk neutral.

I assume that the price of both certified and uncertified products is set competitively. Uncertified products costs zero and are produced at zero costs. Moreover, all producers take the quality of certification process $q$ and fee for certification $f$ as a given. I will show that both separating and pooling equilibria exist, depending on the price of certification $f$ and the probability of error in testing $q$. This requires that the certifiers are committed to the price and quality of testing.

\subsection{Three equilibria}

Three types of equilibria exist. First, if the certification fee $f$ is very high, neither high nor low quality producers will apply, and no certified products will be traded. The other two equilibria are more interesting.

The participation of high quality producers depends on price $p$ for which certified products are sold, the probability that they will obtain a certificate, and the costs of certification and production. Marginal high-quality producers have production costs $s_{h}$

$$
(1-q) p-f-s_{h}=0
$$

assuming that an outside option has zero value. The number of high-quality producers applying for a certificate is thus $(1-q) p-f$. There are no high-quality producers selling organic products without a certificate since such products would be indistinguishable from (a large number of) low-quality products and of zero price.

Since the testing technology is noisy and high quality production is expensive, some low-quality producers may attempt to obtain a certificate. If these producers expect positive profit $p q-f>0$ from such an attempt, they will apply, until the expected profits return to zero.

If expected profit of low-quality producers attempting to obtain a certificate is neg- 
ative

$$
p q-f<0,
$$

there will be only high-quality producers applying for a certificate in equilibrium. Note that any applicant has to pay a fee, regardless of whether he obtains a certificate or not. This is in fact how most certification systems work.

I analyze these types of equilibria separately, starting with the pooling one, in which some low and high quality producers apply for a certificate. If the certification is too costly $(f>A(1-q))$, there is no certification in the equilibrium. The other two types are more interesting: a pooling and a separating equilibrium.

\subsubsection{Pooling equilibrium}

Since the expected profit on the uncertified market is zero, all low-quality producers have to be indifferent between application for a certificate and low-quality production. Market equilibrium conditions then determine how many low-quality producers will apply. These conditions are:

- The participation of high quality producers

$$
(1-q) p-f-s_{h}=0
$$

- Zero profit of low-quality producers

$$
p q-f=0
$$

- A definition of quality for the certificate (the probability that a product with a certificate is in fact of high quality), depending on the probability of mistake $q$ is

$$
s=\frac{(1-q) s_{h}}{(1-q) s_{h}+q s_{l}} .
$$


- Finally, the market equilibrium on certified products market requires

$$
A-\frac{p}{s}=(1-q) s_{h}+q s_{l}
$$

where $s_{l}$ is a measure of low-quality producers applying for a certificate, and $s_{h}$ is a measure of high-quality producers. It may happen that $s \notin[0,1]$; then, the equilibrium does not exist.

Lemma 1. For any quality of testing technology $q \in(0,0.5)$, fee $f^{*}$ exists such that for any $f, 0<f<f^{*}$, there is an equilibrium with a positive measure of low-quality producers attempting to obtain a certificate, where

$$
f^{*}=A \frac{q}{2 q^{2}-3 q+2} .
$$

This function is increasing in q. The equilibrium is described by equations

$$
\begin{aligned}
s_{l} & =\frac{(1-2 q)(1-q)}{q^{2}\left(2-3 q+2 q^{2}\right)}\left(A q-f\left(2-3 q+2 q^{2}\right)\right), \\
s_{h} & =f \frac{1-2 q}{q} \\
s & =\frac{f}{A q}\left(2 q^{2}-3 q+2\right), \text { and } \\
p & =\frac{f}{q} .
\end{aligned}
$$

When the testing technology is perfect $(q=0)$, no low-quality producers will enter even if it is costless to do so. As the technology becomes more imperfect, the chances of success increase, and thus low-quality producers are willing to pay more for an attempt to get a certificate.

\subsubsection{Separating equilibrium}

There is a separating equilibrium in which no low-quality producers apply for a certificate because expected profit from doing so is negative. In this equilibrium, the certification 
perfectly separates high and low-quality producers. I assume that high-quality producers still fail certification tests with probability $q$. This assumption implies that certifiers do not observe that only high-quality producers are applying for the certificate or are unable to skip the testing. Thus, they conduct the tests of the same quality as when some low-quality producers are applying.

Since there are no low-quality producers applying in a separating equilibrium, all certified products are of high quality $(s=1)$. Since mistakes happen with probability $q$, only $1-q$ share of applying producers will obtain a certificate despite the fact that they are all high-quality producers. ${ }^{10}$ The market equilibrium conditions are

$$
\begin{aligned}
A-p & =(1-q) s_{h}, \\
(1-q) p-f-s_{h} & =0 .
\end{aligned}
$$

The constraint of this equilibrium is that expected profit of low-quality producers is not positive

$$
q p \leq f .
$$

One can show that the condition which guarantees existence of separating equilibria is complementary to the existence of the condition of pooling equilibria.

Lemma 2. A lower and upper boundary on fee $f$ existssuch that honest equilibrium exists only for $f$ between these boundaries. I denote the lower boundary by $f^{*}$ and the upper boundary $f^{* *}$. It holds that

$$
f^{*}=A \frac{q}{2 q^{2}-3 q+2}
$$

and

$$
f^{* *}=A(1-q)
$$

\footnotetext{
${ }^{10}$ This requires that certifiers are committed to do the tests. Without this commitment, there would be no separating equilibrium.
} 
The price of organic products in honest equilibrium is $p=\frac{A+f(1-q)}{(q-1)^{2}+1}$. The number of highquality producers applying for a certificate is

$$
s_{h}=\frac{A(1-q)-f}{(1-q)^{2}+1} .
$$

These results are summarized in the following corollary.

Corollary 1. For a combination of $(f, q)$ such that $f<A(1-q)$, a unique equilibrium exists.

- If $f \leq A \frac{q}{2 q^{2}-3 q+2}$ in this equilibrium ${ }^{11}$ some low-quality producers apply for a certificate.

- If $f>A \frac{q}{2 q^{2}-3 q+2}$, then no low-quality producers apply, and thus, all certified products are of high quality.

- If $f>A(1-q)$, then no producers apply for a certificate in the equilibrium.

The partition of the parameter space is depicted on the following picture.

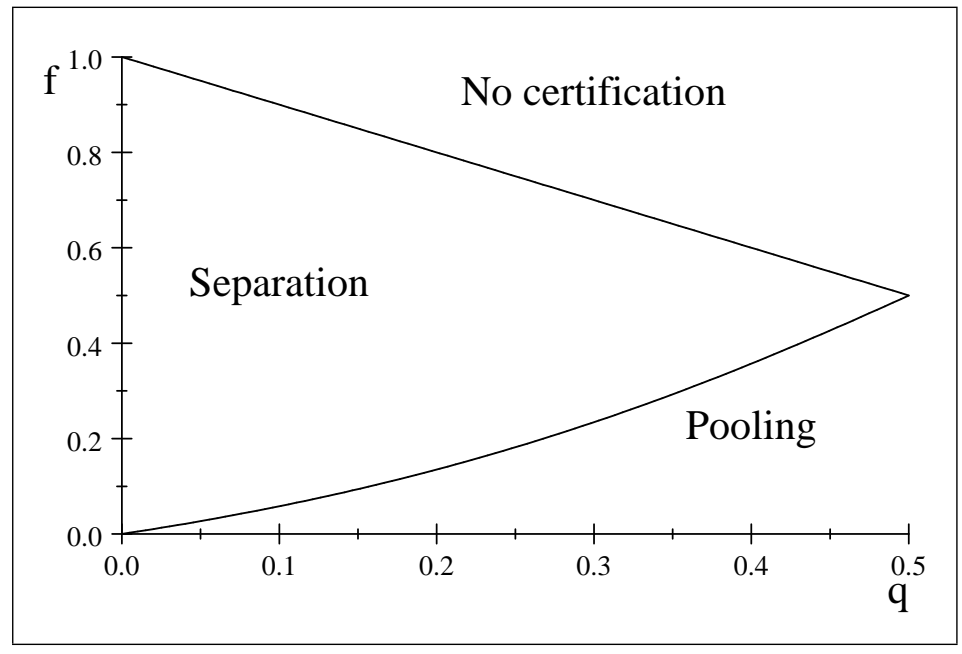

Equilibria depending on certification fee $f$ and probability of mistake during testing $q$.

${ }^{11}$ In a pooling equilibrium, there is additional an constraint $p<A$, which is equivalent to $f<A q$. This constraint is not binding because $2 q^{2}-3 q+2>1$, and thus, I have

$$
f \leq A \frac{q}{2 q^{2}-3 q+2}<A q
$$


Note that the equilibria coincide for $f=A \frac{q}{2 q^{2}-3 q+2}$. There are no low-quality producers applying, but the their expected value of entry is zero. For $f>A \frac{q}{2 q^{2}-3 q+2}$, the expected value for low-quality producers is strictly negative.

\subsection{Welfare}

In the previous section, I have shown that the certification fee determines whether lowquality producers will apply for a certificate. For a fee sufficiently low, they will find it profitable to do so. Yet, it is not obvious whether the benefits of a lower certification fee for high-quality producers and consumers exceed the loss from low-quality products being certified. This section analyzes where the welfare optimum lies.

I compute the welfare by finding consumers' surplus and producers' production costs. For simplicity, I assume that low-quality products have zero value and that high quality producers that do not obtain a certificate by error will sell their products to consumers who do not value it. For now, I also assume that the testing technology is costless and certification fees are thus mere transfers.

The welfare function is then

$$
W=\frac{1}{2}\left(s A^{2}-\frac{p^{2}}{s}-s_{h}^{2}\right)
$$

which in separating equilibrium is

$$
W^{s}=\frac{1}{2\left(q^{2}-2 q+2\right)}\left(A^{2}(1-q)^{2}-f^{2}\right) .
$$

In a pooling equilibrium, it becomes

$$
W^{p}=\frac{1}{2} \frac{f}{q^{2}} \frac{(1-2 q)^{2}}{2 q^{2}-3 q+2}\left(A \frac{q(1-q)}{1-2 q}\left(3-3 q+2 q^{2}\right)-f\left(2-3 q+2 q^{2}\right)\right) .
$$

The following results summarize the behavior of welfare. 
Lemma 3. Welfare in a separating equilibrium is decreasing in fee $f$, but increasing in $f$ in a pooling equilibrium. ${ }^{12}$ Since the equilibria coincide for $f^{*}=A \frac{q}{2 q^{2}-3 q+2}$, this is where the welfare is maximized. Welfare is increasing in quality $q$ in both equilibria. When no certification takes place, welfare is zero.

This result has an intuitive explanation. It is obvious that welfare improves when the certification fee is reduced in a separating equilibrium. In a pooling equilibrium (or at the border between pooling and separating equilibrium), when the certification fee is reduced, some more high quality producers find it profitable to enter the market, and if they obtain a certificate, they sell the product and thus improve the welfare. However, these marginal high-quality producers are facing the highest production costs and sell to the marginal consumer, ie., to the consumer with the lowest valuation still purchasing the good. In contrast, a successful low-quality producer sells to a randomly chosen consumer.The loss is higher than the benefit and thus the welfare optimum does not lie in the pooling equilibrium region.

While the previous result assumes no certification costs, the result holds even for the constant marginal cost of each test.

Lemma 4. If there are constant marginal costs for certification smaller than fee $f$, the welfare optimal equilibrium does not change.

Proof. It is easy to show that in the case of constant marginal costs $c$, the partial derivative of welfare with respect to certification fee $f$ is

$$
\frac{\partial W^{s}}{\partial f}=\frac{c-f}{q^{2}-2 q+2}
$$

and thus the welfare is decreasing in $f$ as long as $c<f$, in an honest equilibrium. A similar analysis in the case of cheating equilibrium shows that welfare is also highest for the highest possible fee, as before. Since with such a fee the welfare in honest equilibrium

\footnotetext{
${ }^{12}$ Welfare in pooling equilibrium depends on $f$ non-linearly, but it is easy to show that in the relevant range of $f$, the welfare is increasing in $f$.
} 
and cheating equilibrium coincide, the overall welfare optimum requires $f=A \frac{q}{2 q^{2}-3 q+2}$.

The assumption $c<f$ is reasonable, since this is a necessary condition for certifiers to make positive profit. Therefore, for a given quality of testing technology, a welfare optimising regulator would attempt to reduce certification fees up to the point where low-quality producers are indifferent between entering and staying out of the certified market but do not actually enter.

\subsubsection{The effect of competition}

First, I discuss the results from the previous section in the case where the quality of the testing technology $q$ is given. I focus on the effect that the competition may have on the certification fee.

Corollary 2. If competition between certifiers lowers the fee and does not change the quality of testing, it is beneficial in separating equilibrium, but not in a pooling equilibrium. Moreover, fees determine which equilibrium is viable. If fee $f$ is too low, separating equilibrium is not viable. It is possible to show that both equilibria may exist, depending on the expectations of certifiers and producers.

Even if the competition between certifiers does not have any impact on the quality of the technology $q$ and just lowers the certification fee $f$, this result shows that "too much" competition reduces fee $f$ below $f^{*}$ and encourages the entry of cheating producers. Even though high quality producers benefit from a lower fee, the overall welfare effect is not positive - welfare is maximized in the separating equilibrium with the lowest possible fee.

It is possible that for a given number of competing certifiers, both equilibria may be viable. If all certifiers somehow coordinate on high fee $f$, for a given quality $q$, no lowquality producer will enter. Similarly, if certifiers coordinate on a low fee, low-quality producers enter. One equilibrium may dominate the other in terms of welfare or profits of the certifiers. 
Further motivation of introducing competition between certifiers comes from the conjecture that lower fees will result in lower prices of certified products. It is easy to observe that this is true in both equilibria. However, the welfare results show that lower prices do not necessarily imply welfare improvement.

Corollary 3. Price is increasing in fee $f$ in both equilibria. The share of high quality products and participation of high quality producers are increasing in fee $f$ in pooling equilibrium, but the participation of low-quality producers is decreasing in $f$. The participation of high quality producers in a separating equilibrium is decreasing in $f$.

This result confirms that the intuition that a lower fee decreases the prices of organic food is correct, but it is incomplete. Lowering certification fees encourages the entry of low-quality producers, which has overall negative consequences on welfare.

\subsubsection{Certifiers' revenue}

In this section, I show that a monopoly, profit-maximizing, certifier does not charge a welfare optimal fee for a given quality of testing technology. ${ }^{13}$

Proposition 1. If the testing technology is costless, the fee that maximizes total revenue of all certifiers in a pooling equilibrium is

$$
f_{p}^{\Pi}=A \frac{1}{2} q \frac{1-q}{(1-2 q)\left(2-3 q+2 q^{2}\right)}, \text { for } q<A \frac{q}{2 q^{2}-3 q+2}
$$

For $q \geq A \frac{q}{2 q^{2}-3 q+2}$, the constraint $f \leq f^{*}=A \frac{q}{2 q^{2}-3 q+2}$ is binding. The fee that maximizes revenue in separating equilibrium is

$$
f_{s}^{\Pi}=\frac{1}{2} A(1-q), \text { for } q<0.37
$$

If the technology is costless, the highest possible revenue in separating equilibrium is

\footnotetext{
${ }^{13} \mathrm{~A}$ welfare maximizing not-for-profit certifier would choose the welfare optimal fee $f^{*}=\frac{A q}{2 q^{2}-3 q+2}$.
} 
always bigger or equal to the revenue of all certifiers in pooling equilibrium.

$$
\Pi^{p} \leq \Pi^{s}
$$

This result shows that some competition is beneficial. A monopoly certifier that maximizes its revenue (or profit, in the case of costless testing technology) will choose a welfare sub-optimal fee. In the case of separating equilibrium, the revenue maximizing fee is too large, as expected. Interestingly, in the case of pooling equilibrium, such a fee is lower than the welfare optimal.

\subsection{Technology and competition}

The previous section discusses the benefits of competition between certifiers if the quality of testing technology is fixed. Because of the incentive structure, I will argue that this represents an optimistic scenario and that one may expect a decrease in quality of testing technology when the competition becomes more intensive.

I assume that producers are not able to observe the quality of testing technology of individual certifiers. High-quality producers have an incentive to find higher quality certifiers because this reduces the probability of a mistakingly rejected application. However, this is sensitive to the assumptions. For example, if a lower quality of testing simply means less inspection, even high-quality producers might benefit from certification by a certifier of lower quality. If testing technology is asymmetric and high-quality producers always pass the certification, regardless of the quality that only affects lowquality producers, there are no incentives to learn about the quality of certification by them. Low-quality producers always have the incentive to find a certifier of lower quality because this increases their chances of passing the test.

Thus, one cannot hope that there would be a significant pressure from high-quality producers to motivate certifiers to improve testing technology, especially if the errors do not harm them. Competition may dilute incentives of certifiers to invest into the quality 
of testing technology. For example, if the certifiers have to first invest into testing technology before they compete in prices, then a monopoly certifier would fully internalize the impact of quality on demand for certificates. If there are competing certifiers, better testing technology by one certifier affects the revenue of all certifiers. More intense competition thus may reduce the incentive of a certifier to invest. This argument requires that the overall demand is increasing in quality of the testing technology. I confirm that this is indeed true in a separating equilibrium. It is also true in the pooling equilibrium for $f=f^{*}$, as long as the quality of the testing technology is not too low.

Lemma 5. Number of producers applying for a certificate increases when the quality of testing increases

$$
\frac{\partial s_{h}}{\partial q}=\frac{-1}{\left(q^{2}-2 q+2\right)^{2}}(A q(2-q)+2 f(1-q))<0
$$

in a separating equilibrium, but not necessarily in a pooling one. For the highest possible fee, $f^{*}=A \frac{q}{2 q^{2}-3 q+2}$, which is consistent with the pooling equilibrium and the demand is increasing in quality

$$
\frac{\partial\left(s_{h}+s_{l}\right)}{\partial q}=\frac{A}{q^{2}\left(2 q^{2}-3 q+2\right)^{2}}\left(-4 q^{4}+4 q^{3}+5 q^{2}-8 q+2\right) .
$$

This expression is positive for a sufficiently low fee $f$.

A more general model of competition between certifiers will need to incorporate possibly different certification fees and different qualities of the testing. This is a interesting notion for future research, but it is beyond the scope of the current paper.

\subsection{Type $I$ and type $I I$ errors}

Previous analysis suggests that improving the testing technology always improves the welfare. However, it seems possible that such an outcome is a consequence of a particular assumption about the testing technology - the fact that the probability of rejecting a 
high-quality producer and awarding a certificate to a low-quality one is the same. Such symmetry in the technology is certainly possible, yet not likely. Therefore, I extend the model by distinguishing the probabilities of "type $I$ " and "type $I I$ " errors. ${ }^{14}$

I denote the probability that a high-quality producer does not pass the certification tests as $q_{1}$. The probability that a low-quality producer passes the test will be denoted by $q_{2}$. The analysis is very similar to the previous section, though slightly more technical. All three types (separating, pooling, and no-certification) of equilibria still exist.

\subsubsection{Pooling equilibrium}

The basic results are very similar to the previous section.

Lemma 6. Pooling equilibrium exists for fee $f$, which is sufficiently low

$$
f_{e}^{*}=A \frac{q_{2}}{-2 q_{1}-q_{2}+q_{1}^{2}+q_{1} q_{2}+2} .
$$

It is characterized by

$$
\begin{aligned}
s_{l} & =\frac{1}{q_{2}^{2}}\left(1-q_{1}\right)\left(1-q_{1}-q_{2}\right)\left(A \frac{q_{2}}{q_{1}^{2}-q_{2}-2 q_{1}+q_{1} q_{2}+2}-f\right) ; \\
s_{h} & =\frac{f}{q_{2}}\left(1-q_{1}-q_{2}\right) ; \text { and } \\
s & =\frac{1}{A} \frac{f}{q_{2}}\left(q_{1}^{2}-q_{2}-2 q_{1}+q_{1} q_{2}+2\right) .
\end{aligned}
$$

\subsubsection{Separating equilibrium}

In a separating equilibrium, expected profit of low-quality producers is negative, while a marginal high-quality producer makes zero profit. Thus, probability $q_{2}$ determines the viability of separating equilibria, while probability $q_{1}$ determines its properties.

\footnotetext{
${ }^{14}$ If one considers the testing procedure as a test with a null hypothesis the "product is of high quality", then the probability of type $I$ error is the probability that a high-quality product will be judged to be of low quality (false positive). Type $I I$ error is then a probability that a low-quality producer will be judged to be of high quality (false negative).
} 
Lemma 7. For fee $f$ bigger than $f_{e}^{*}$,

$$
f_{e}^{*}=A \frac{q_{2}}{-2 q_{1}-q_{2}+q_{1}^{2}+q_{1} q_{2}+2}
$$

but smaller than $A\left(1-q_{1}\right)$, a separating equilibrium exists, in which the number of applying high-quality producers is

$$
s_{h}=\frac{A\left(1-q_{1}\right)-f}{\left(1-q_{1}\right)^{2}+1} .
$$

\subsubsection{Welfare}

Since I distinguish two types of errors, I may study which error has a bigger influence on welfare. If it is technologically possible to reduce $q_{1}$ or $q_{2}$, such a result tells us where one should focus the bigger investment.

Lemma 8. Welfare in separating equilibrium depends only on $q_{1}$.

$$
W_{e}^{s}=\frac{1}{2\left(q_{1}^{2}-2 q_{1}+2\right)}\left(A^{2}\left(q_{1}-1\right)^{2}-f^{2}\right)
$$

Improving the quality of testing technology increases the welfare.

$$
\frac{\partial W_{e}^{s}}{\partial q_{1}}=\left(q_{1}-1\right) \frac{A^{2}+f^{2}}{\left(q_{1}^{2}-2 q_{1}+2\right)^{2}}<0 .
$$

In the pooling equilibrium, first derivatives of the welfare function are quite technical, and I therefore present those in a special case $q=q_{1}=q_{2}$. The welfare function itself is

Lemma 9. Welfare is increasing in $f$ in the relevant range. Reducing the probability of either error is welfare improving

$$
\left.\frac{\partial W^{p}}{\partial q_{1}}\right|_{q_{1}=q_{2}}<0,\left.\frac{\partial W^{p}}{\partial q_{2}}\right|_{q_{1}=q_{2}}<0
$$


moreover, reducing type II error improves welfare more than reducing type I error.

$$
\frac{\left.\frac{\partial W^{p}}{\partial q_{1}}\right|_{q_{1}=q_{2}}}{\left.\frac{\partial W^{p}}{\partial q_{2}}\right|_{q_{1}=q_{2}}} \leq 1,
$$

for any $f \leq f^{*}=A \frac{q}{2 q^{2}-3 q+2}, q<0.5$.

These results assume that the testing technology is costless and suggest that if the marginal improvement of the testing technology is equally costly if $q_{1}=q_{2}$, then it is welfare optimal to reduce $q_{2}$ instead of $q_{1}$, in the pooling equilibrium. In a separating equilibria, $q_{2}$ only co-determines whether separating equilibrium is viable. Still, it might be more beneficial to reduce $q_{2}$, which allows separating equilibrium for the lower fee $f$.

Lemma 10. If high-quality producers always pass the test $\left(q_{1}=0\right)$, then the marginal effect on welfare from an increase in $q_{2}$ is bigger than $q_{1}$ if $\frac{A}{f}$ is high and $q_{2}$ is small. ${ }^{15}$

If $\frac{A}{f}$ is high, the value of high-quality products is high relatively to the certification fees. Thus, not certifying high-quality producers is more harmful than erroneously certifying low-quality ones. Also, if the probability of error for low-quality producers $\left(q_{2}\right)$ is already high, further marginal increase has lower impact than the same marginal change in $q_{1}$.

\subsubsection{Quality of testing and the type of equilibria}

The borderline fee $f_{e}^{*}$ that separates pooling and separating equilibrium depends on both $q_{1}$ and $q_{2}$ :

$$
f_{e}^{*}=A \frac{q_{2}}{-2 q_{1}-q_{2}+q_{1}^{2}+q_{1} q_{2}+2}
$$

Lemma 11. Improving technology (lowering $q_{1}$ or $q_{2}$ ) lowers the borderline fee $f_{e}^{*}$. Moreover, lowering $q_{2}$ always reduces the fee $f^{*}$ more.

This results show that reducing type II error $\left(q_{2}\right)$ thus reduces the optimal fee $f_{e}^{*}$ more than reducing type $I$ error.

\footnotetext{
${ }^{15}$ Note that increasing $q_{i}$ means that the technology gets worse as $q_{i}$ denotes the probability of the error.
} 


\subsubsection{Profits and quality of technology}

Let's analyze the incentives that the certifiers' industry has for investment into testing technology. Revenues of certifiers in separating equilibria are

$$
\begin{aligned}
\Pi^{h} & =f \frac{A\left(1-q_{1}\right)-f}{\left(1-q_{1}\right)^{2}+1} \\
\frac{\partial \Pi^{h}}{\partial q_{1}} & =\frac{f}{\left(q_{1}^{2}-2 q_{1}+2\right)^{2}}\left(-2 f\left(1-q_{1}\right)-A q_{1}\left(2-q_{1}\right)\right)<0 .
\end{aligned}
$$

So certifiers have some incentives to invest into the testing technology, though it is not clear whether they are sufficient.

In a pooling equilibrium, the situation is even less clear

Lemma 12. Improving testing technology in a pooling equilibrium increases the total profit of certifiers only if the technology is already sufficiently good and certification fees are high enough. For example, at fee $f_{e}^{*}$, any improvement in the testing technology increases profit of the certifiers for $q<q^{* *}$.

These results suggest that a monopoly certifier would have some positive incentives into testing technology. Competition between certifiers is likely to dilute these incentives as there are positive externalities from investment that cannot be fully internalized.

\section{Conclusion}

This paper studies the adverse selection of low-quality producers in imperfect certification. The previous literature (Strausz 2005) shows that high fees are required to keep a certifier honest. On top of that, I show that high certification fees also discourage the entry of low-quality producers. In the case of imperfect testing technology, this improves the reliability of the certificate and is in fact welfare improving.

I applied this result in discussing the extent to which competition between certifiers lowering certification fees is optimal. I show that a monopoly certifier chooses a too high certification fee, but achieves separation. Introducing too many competing certifiers may 
lower the certification fee below the minimal level consistent with the welfare optimal result and thus be harmful.

I also extend the model to allow for the different probability of type I and type II error. I show that reducing any error is welfare improving. In an equilibrium, where some low-quality producers apply for a certificate, reducing the probability that such producers would succeed in certification increasesthe welfare more than reducing the probability that a high-quality producer will fail the certification process. Intuition for this result comes from the fact that not admitting a high-quality producer harms marginal consumers, who have the lowest valuation of organic food, but admitting low quality producers harms the average consumer, which translates into a lower price of certified products and thus harms other producers. In a separating equilibria, reducing type II error reduces the minimal fee consistent with separation more than reducing type I error does, but this does not have direct effect on welfare. I also show that the overall revenues of certifiers are decreasing in type I error in a separating equilibrium, which suggests that certifiers have some incentives to improve the testing technology. Even though I do not model the competition between certifiers explicitly, I argue that competition reduces these incentives and thus may lead to a lower investment into testing technology. ${ }^{16}$

The main drawback of this analysis comes from the lack of an explicit model of competition both in prices and quality of testing. While I argue that simply to lower the fee reduces the viability of separating equilibrium, it is likely that competition also reduces the incentives to invest into testing technology and thus leads to lower quality. This would have two negative effects. First is similar to a reduction in fee $f$, and impacts the viability of the separating equilibrium. The other impact is direct-I have shown that welfare is affected negatively if the quality of testing technology decreases.

Another limitation of this analysis comes from the fact that I model quality $q$ and

\footnotetext{
${ }^{16}$ The intuition is clear. If each certifier has a smaller market share, improving the technology benefits not only him, but other certifiers as well. Since he cannot internalize these benefits as a single monopoly certifier would, one can expect lower investment in equilibrium when more competitors are present.
} 
certification fee $f$ as uniform across certifiers. It is not trivial to see how producers would behave in an environment in which they can choose from a menu of certifiers with different testing technologies and different fees. Moreover, it is not clear how should the certifiers choose the quality of the testing technology and price their services. These issues are left for future research.

I have also assumed that all producers applying for a certificate pay the same certification fee $f$. Other assumptions are clearly possible. For example, producers that successfully obtain a certificate may be granted a partial refund of the certification fee. This would increase the payoff for both high- and low-quality producers. Because of the higher probabililty of success of high-quality producers, the effect would be stronger for them than for low-quality producers. The region of the separating equilibria would thus be larger. Depending on the size of the refund, the region of no viable certification would shrink. One might also consider a fine for unsuccessful producers, which would be very similar to the partial refund of the certification fee $f$.

Finally, I have assumed commitment to a given quality of testing technology $q$. Given the structure of, for example, organic certification, it is clear that to sustain a low probability of error and thus low a pass-rate of low quality (non-organic) producers, some supervision of the certifiers must be in place. Current requirements on certifiers mostly focus on their qualification, but very little is known about the actual supervision. A deeper understanding of how supervision should work and how much is required will help us to understand more issues of competition between certifiers. Since certifier profits are likely to increase when the competition intensifies, the results of Strausz (2005) suggest that it may be harder to sustain honesty certification.

\section{Appendix}

\section{Proof of Lemma 1.}

It is trivial to verify that equations (1-4) have a solution (5-8). The upper bound on fee $f^{*}$ comes from the condition that a non-negative number of low-quality producers 
applies for a certificate

$$
\frac{(1-2 q)(1-q)}{q^{2}\left(2-3 q+2 q^{2}\right)}\left(A q-f\left(2-3 q+2 q^{2}\right)\right) \geq 0 \Longleftrightarrow f \leq \frac{A q}{2-3 q+2 q^{2}} .
$$

For a boundary value of fee $f^{*}=\frac{A q}{2-3 q+2 q^{2}}$, no low-quality producers apply for a certificate and the expected value of doing so is zero. For higher fees, the expected value of an application is negative for low-quality producers.

\section{Proof of Lemma 2.}

In a separating equilibrium, it has to be true that no low-quality producer applies for a certificate. This happens when the expected value of doing so is negative $(p q-$ $f<0)$. Then, there are no low-quality producers having a certificate $(s=1)$. The equilibrium conditions then become simply (9-10). The value of fee $f$ is constrained by the condition $p q-f<0$. The other condition in equilibrium guarantees that in a separating equilibrium, high-quality producers prefer to apply for a certificate. If $f=p=A(1-q)$, then only the high-quality producer will apply for a certificate since his production costs are zero, certification costs and expected revenue are equal to $A(1-q)$. This clearly describes the extreme value of $f$. For any fee higher than $A(1-q)$, no certification can take place in equilibrium.

\section{Proof of Lemma 3.}

First, let's derive the function of total welfare. Since both the price of goods and the price of certification represent a transfer, I can compute the welfare as a difference between consumers' utility and production costs

$$
W=\int_{\frac{p}{s}}^{A} s x d x-\int_{0}^{s_{h}} x d x=\frac{1}{2}\left(s A^{2}-\frac{p^{2}}{s}-s_{h}^{2}\right) .
$$

The welfare function in a separating and pooling equilibrium can be easily derived by plugging in the equilibrium values of relevant variables $\left(s, p, s_{h}\right)$.

It is straight forward to compute the derivative of both welfare functions (equations 
11, 12).

$$
\begin{aligned}
\frac{\partial W^{s}}{\partial f} & =-\frac{f}{q^{2}-2 q+2} \leq 0 ; \\
\frac{\partial W^{p}}{\partial f} & =-\frac{1}{2 q^{2}} \frac{1-2 q}{2 q^{2}-3 q+2}\left(A q\left(6 q-5 q^{2}+2 q^{3}-3\right)+f\left(4+16 q^{2}-8 q^{3}-14 q\right)\right) .
\end{aligned}
$$

The sign $\frac{\partial W^{p}}{\partial f}$ is positive if

$$
f \leq A q \frac{-6 q+5 q^{2}-2 q^{3}+3}{4+16 q^{2}-8 q^{3}-14 q} .
$$

Since in a pooling equilibrium for any fee $f$ such that

$$
f<f^{*}=\frac{A q}{2 q^{2}-3 q+2} \leq A q \frac{-6 q+5 q^{2}-2 q^{3}+3}{4+16 q^{2}-8 q^{3}-14 q}
$$

the welfare in a pooling equilibrium is increasing in $f$.

One can easily verify:

$$
\begin{aligned}
\frac{\partial W^{s}}{\partial q} & =\left(A^{2}+f^{2}\right) \frac{q-1}{\left(q^{2}-2 q+2\right)^{2}}<0 ; \\
\frac{\partial W^{p}}{\partial q} & \left.=\frac{f}{q^{3}\left(2 q^{2}-3 q+2\right)^{2}}(f X+A q Y)\right)<0, \text { and } \\
X & =4+41 q^{2}-46 q^{3}+28 q^{4}-8 q^{5}-20 q, \\
Y & =9 q-10 q^{2}+13 q^{4}-12 q^{5}+4 q^{6}-3 .
\end{aligned}
$$

The expression $\frac{\partial W^{p}}{\partial q}$ is negative if

$$
f<A q \frac{\left(-9 q+10 q^{2}-13 q^{4}+12 q^{5}-4 q^{6}+3\right)}{\left(4+41 q^{2}-46 q^{3}+28 q^{4}-8 q^{5}-20 q\right)} .
$$

As before, it holds that

$$
f^{*}=\frac{A q}{2 q^{2}-3 q+2} \leq A q \frac{\left(-9 q+10 q^{2}-13 q^{4}+12 q^{5}-4 q^{6}+3\right)}{\left(4+41 q^{2}-46 q^{3}+28 q^{4}-8 q^{5}-20 q\right)},
$$


and thus welfare is decreasing in the probability of error $q$ (or increasing in the quality of testing technology $1-q$ ) in the relevant range of fees.

\section{Proof of Lemma 4.}

If each test costs the certifier $c$, then the welfare function has to be modified

$$
W=\frac{1}{2}\left(s A^{2}-\frac{p^{2}}{s}-s_{h}^{2}\right)-c\left(s_{l}+s_{h}\right) .
$$

In a separating equilibrium, this becomes

$$
\begin{aligned}
W^{s} & =\frac{1}{2} \frac{A(1-q)-f}{q^{2}-2 q+2}(A(1-q)-2 c+f), \\
\frac{\partial W^{s}}{\partial f} & =\frac{c-f}{q^{2}-2 q+2}<0 .
\end{aligned}
$$

The expression for $W^{p}$ is technical but easy to obtain. Its derivative with respect to the fee is

$$
\frac{\partial W^{p}}{\partial f}=\frac{1}{2 q^{2}} \frac{1-2 q}{2 q^{2}-3 q+2}\left((c-f)\left(4+16 q^{2}-8 q^{3}-14 q\right)+A q\left(3-6 q+5 q^{2}-2 q^{3}\right)\right)
$$

which is positive because

$$
A q \frac{\left(3-6 q+5 q^{2}-2 q^{3}\right)}{4+16 q^{2}-8 q^{3}-14 q}>A q \frac{1}{2 q^{2}-3 q+2}>f^{*}>f-c
$$

Thus, the welfare optimum does not change as long as the constant marginal costs of testing are smaller than the fee $f$.

\section{Proof of Proposition 1.}

The proof of this proposition is straight forward. Let's compute the total revenues of all certifiers, or their profits in the case of costless testing technology in separating 
and pooling equilibria:

$$
\begin{aligned}
\Pi^{s} & =f s_{h}=f \frac{A(1-q)-f}{(1-q)^{2}+1} \\
\Pi^{p} & =f\left(s_{l}+s_{h}\right)=f \frac{2 q-1}{2 q^{4}-3 q^{3}+2 q^{2}}\left(2 f+A q^{2}+8 f q^{2}-4 f q^{3}-A q-7 f q\right) .
\end{aligned}
$$

Taking a partial derivative with respect to $f$ gives the first order conditions

$$
\begin{aligned}
& \frac{\partial \Pi^{s}}{\partial f}=-\frac{2 f-A+A q}{q^{2}-2 q+2}, \text { and } \\
& \frac{\partial \Pi^{p}}{\partial f}=\frac{1}{q^{2}} \frac{2 q-1}{2 q^{2}-3 q+2}\left(4 f+A q^{2}+16 f q^{2}-8 f q^{3}-A q-14 f q\right) .
\end{aligned}
$$

The maximum is reached at $f_{s}^{\Pi}=\frac{1}{2} A(1-q)$ in a separating equilibrium and

$$
f_{p}^{\Pi}=\frac{1}{2} \frac{A q(1-q)}{(1-2 q)\left(2-3 q+2 q^{2}\right)} .
$$

Note that $f_{p}^{\Pi}$ is constrained from above by the condition $f \leq f^{*}=A \frac{q}{2 q^{2}-3 q+2}$. This constraint is binding from $q=\frac{1}{3}$. Similarly, $f_{s}^{\Pi}$ is bounded from below by the same expression:

$$
\frac{1}{2}(1-q)=\frac{q}{2 q^{2}-3 q+2}
$$

for $q>q^{*}=0.369$. The profit functions are then

$$
\begin{aligned}
& \Pi_{\max }^{s}=\frac{1}{4} A^{2} \frac{(q-1)^{2}}{q^{2}-2 q+2} \\
& \Pi_{\max }^{p}=A^{2} \frac{(q-1)^{2}}{16 q^{4}-48 q^{3}+68 q^{2}-48 q+16}, \text { and } \\
& \frac{(q-1)^{2}}{16 q^{4}-48 q^{3}+68 q^{2}-48 q+16}=\frac{1}{4} \frac{(q-1)^{2}}{q^{2}-2 q+2} .
\end{aligned}
$$

It is easy to verify that the maximal profit in the separating equilibrium is higher than in the pooling up to $q^{*}$, after which they coincide.

\section{Proof of Lemma 5.}


The behavior of the demand for certification in separating equilibrium is simply a derivative of the number of certified high-quality producers. Computing the derivative of the number of high- and low-quality producers in a pooling equilibrium, one gets

$$
\begin{aligned}
& \frac{\partial\left(s_{h}+s_{l}\right)}{\partial q}=-\frac{1}{q^{3}\left(2 q^{2}-3 q+2\right)^{2}}\left(A q \left(11 q^{2}-6 q-12 q^{3}+\right.\right. \\
& \left.\left.+2+4 q^{4}\right)+f\left(-8-82 q^{2}+92 q^{3}-56 q^{4}+16 q^{5}+40 q\right)\right) .
\end{aligned}
$$

For borderline fee, $f=A q \frac{1}{2 q^{2}-3 q+2}$, this expression is

$$
\frac{\partial\left(s_{h}+s_{l}\right)}{\partial q}=\frac{A}{q^{2}\left(2 q^{2}-3 q+2\right)^{2}}\left(-4 q^{4}+4 q^{3}+5 q^{2}-8 q+2\right) \text { and }
$$

is positive for $q<0.33$. The demand is thus decreasing in quality up to this point.

\section{Proof of Lemma 6.}

I state the equilibrium equations. Solving them is standard. The participation decision of high-quality producers depends on the probability that they will fail the certification test

$$
\left(1-q_{1}\right) p-f-s_{h}=0
$$

The second constraint requires zero profit of low-quality producers, depending on the probability that a low-quality producer will succeed in the test

$$
p q_{2}-f=0 .
$$

The definition of quality of the certificate (the probability that a product with a certificate is in fact of high-quality), depending on the probabilities of mistakes $q_{1}$ and $q_{2}$ is

$$
s=\frac{\left(1-q_{1}\right) s_{h}}{\left(1-q_{1}\right) s_{h}+q_{2} s_{l}} .
$$


Finally, market equilibrium requires

$$
A-\frac{p}{s}=\left(1-q_{1}\right) s_{h}+q_{2} s_{l}
$$

Proof of Lemma 7. Similar to the proof of Lemma 2, replace $q$ with $q_{1}$ except for the definition of $f^{*}$ from the previous Lemma.

Proofs of Lemma 8 and 9. Proof is very similar to the proof of Lemma 3 and 4 and requires only trivial algebraic manipulations.

\section{Proof of Lemma 10..}

Welfare in a pooling equilibrium is

$$
W_{e}^{p}=\frac{1}{2} \frac{f}{q_{2}^{2}}\left(A \frac{q_{2}\left(1-q_{1}\right)\left(1-q_{1}-q_{2}\right)}{q_{1}^{2}-q_{2}-2 q_{1}+q_{1} q_{2}+2}\left(q_{1}^{2}-q_{2}-2 q_{1}+q_{1} q_{2}+3\right)-f\left(1-q_{1}-q_{2}\right)^{2}\right)
$$

If we compute partial derivatives with respect to $q_{1}$ and $q_{2}$ and plug in $q_{1}=0$, we get the following expressions

$$
\begin{aligned}
& \left.\frac{\partial W_{e}^{p}}{\partial q_{1}}\right|_{q_{1}=0}=-\frac{1}{2} \frac{f}{q_{2}^{2}\left(2-q_{2}\right)}\left(-4 f+5 A q_{2}+6 f q_{2}-4 A q_{2}^{2}+A q_{2}^{3}-2 f q_{2}^{2}\right) ; \text { and } \\
& \left.\frac{\partial W_{e}^{p}}{\partial q_{2}}\right|_{q_{1}=0}=-\frac{f}{q_{2}^{3}\left(-q_{2}+2\right)^{2}}\left(-4 f+3 A q_{2}+8 f q_{2}-3 A q_{2}^{2}+A q_{2}^{3}-5 f q_{2}^{2}+f q_{2}^{3}\right) .
\end{aligned}
$$

If we evaluate the ratio of the first $\left(\frac{\partial W_{e}^{p}}{\partial q_{1}}\right)$ and the second expression $\left(\frac{\partial W_{e}^{p}}{\partial q_{2}}\right)$, we get

$$
\frac{\left.\frac{\partial W_{e}^{p}}{\partial q_{1}}\right|_{q_{1}=0}}{\left.\frac{\partial W_{e}^{p}}{\partial q_{2}}\right|_{q_{1}=0}}=-\frac{1}{2} q_{2}\left(q_{2}-2\right) \frac{5 A q_{2}-4 f+6 f q_{2}-4 A q_{2}^{2}+A q_{2}^{3}-2 f q_{2}^{2}}{3 A q_{2}-4 f+8 f q_{2}-3 A q_{2}^{2}+A q_{2}^{3}-5 f q_{2}^{2}+f q_{2}^{3}} .
$$


For sufficiently large ${ }^{17} \frac{A}{f}$ and small $q_{2}$, the denominator is positive and thus we can write

$$
\begin{gathered}
\left.\frac{\partial W_{e}^{p}}{\partial q_{1}}\right|_{q_{1}=0} \leq\left.\frac{\partial W_{e}^{p}}{\partial q_{2}}\right|_{q_{1}=0} \Longleftrightarrow \\
-\frac{1}{2}\left(q_{2}-1\right)^{2}\left(6 A q_{2}-8 f+8 f q_{2}-4 A q_{2}^{2}+A q_{2}^{3}-2 f q_{2}^{2}\right) \leq 0 .
\end{gathered}
$$

This condition is equivalent to the condition

$$
\frac{A}{f} \geq \frac{8-8 q_{2}+2 q_{2}^{2}}{6 q_{2}-4 q_{2}^{2}+q_{2}^{3}}
$$

or again, that the $q_{2}$ is small and $\frac{A}{f}$ is large, as required in the theorem. Note that this condition is more strict than the condition from the previous footnote.

Proof of Lemma 11 and 12. The proof of these lemmas is straightforward. For Lemma 12 , use $q^{* *}=0.28$.

\section{References}

Biglaiser, G., and J. W. Friedman (1994): "Middlemen as guarantors of quality," International Journal of Industrial Organization, 12, 509-531.

De, S., And P. NABAR (1991): "Economic implications of imperfect quality certification," Economics Letters, 37(4), 333-337.

Epstein, G. S., And I. N. Gang (2002): "The Political Economy of Kosher Wars," Internet:ftp://snde.rutgers.edu/Rutgers/wp/2002-27.pdf, Inocomics.

European Commission (2005a): "List of bodies or public authorities in charge of inspection provided for in article 15 of regulation (EEC) No 2092/91Text with EEA

\footnotetext{
${ }^{17} \mathrm{It}$ is easy to derive the precise requirement:
}

$$
\frac{A}{f}>\frac{4-8 q_{2}+5 q_{2}^{2}-q_{2}^{3}}{q_{2}\left(-3 q_{2}+q_{2}^{2}+3\right)}
$$


relevance," http://eur-

lex.europa.eu/LexUriServ/LexUriServ.do?uri=OJ:C:2005:016:0001:0020:EN:PDF, Official Journal C 016.

(2005b): "Report on the supervision of inspection bodies and authorities of the Member States according to Article 15 of Council Regulation (EEC) No 2092/91 on organic production,"

Internet:http://ec.europa.eu/agriculture/qual/organic/control/report_art15 _ en.pdf, Last accessed: April 26, 2008.

Franzoni, L. A. (1998): "Imperfect Competition in Certification Markets," Internet:http://papers.ssrn.com/sol3/papers.cfm?abstract_id=94052.

Klein, B., And K. B. Leffler (1981): "The Role of Market Forces in Assuring Contractual Performance," The Journal of Political Economy, 89(4), 615-641.

Lizzeri, A. (1999): "Information revelation and certification intermediaries," The RAND Journal of Economics, 30(2), 214-231.

NEW Yorker (2006): "Paradise Sold," http://www.newyorker.com/archive/2006/05/15/060515crat_atlarge, Last accessed: May 11, 2008.

Organic Trade Association (2007): “Organic Trade Association's 2007 Manufacturer Survey," Internet:http://www.ota.com/pics/documents/2007ExecutiveSummary.pdf, Last accessed: April 25, 2008.

Strausz, R. (2005): "Honest certification and the threat of capture," International Journal of Industrial Organization, 23(1-2), 45-62.

Svitkova, K., and A. Ortmann (2006): "Certification As A Viable Quality Assurance Mechanism: Theory and Suggestive Evidence," 
Internet:http://www.cerge-ei.cz/pdf/wp/Wp288.pdf, CERGE-EI Working paper 288.

USDA (2008a): "Certification - Preamble," Inter-

net:http://www.ams.usda.gov/AMSv1.0/getfile?dDocName=STELDEV3003513, Last accessed: April 28, 2008.

(2008b): "Labeling Packaged Products," Inter-

net:http://www.ams.usda.gov/AMSv1.0/getfile?dDocName=STELDEV3004323, Last accessed: April 25, 2008.

_ (2008c): "National Organic Program: Suspensions and Revocations," Internet:http://tinyurl.com/3k2nvy, Last accessed: April 25, 2008.

(2008d): "Organic Production and Handling Standards," Inter-

net:http://www.ams.usda.gov/AMSv1.0/getfile?dDocName=STELDEV3004445, Last accessed: April 25, 2008.

(2008e): "U.S. certified organic farmland acreage, livestock numbers, and farm operations, 1992-2005,"

Internet:http://www.ers.usda.gov/Data/Organic/Data/Farmland

\%20livestock\%20and\%20farm\%20ops\%2092-05.xls, Last accessed: April 25, 2008.

Viscusi, W. K. (1978): “A Note on 'Lemons' Markets with Quality Certification," The Bell Journal of Economics, 9(1), 277-279. 
Individual researchers, as well as the on-line and printed versions of the CERGE-EI Working Papers (including their dissemination) were supported from the following institutional grants:

- Center of Advanced Political Economy Research [Centrum pro pokročilá politickoekonomická studia], No. LC542, (2005-2009),

- Economic Aspects of EU and EMU Entry [Ekonomické aspekty vstupu do Evropské unie a Evropské měnové unie], No. AVOZ70850503, (2005-2010);

- Economic Impact of European Integration on the Czech Republic [Ekonomické dopady evropské integrace na ČR], No. MSM0021620846, (2005-2011);

Specific research support and/or other grants the researchers/publications benefited from are acknowledged at the beginning of the Paper.

(c) Jan Mysliveček, 2008.

All rights reserved. No part of this publication may be reproduced, stored in a retrieval system or transmitted in any form or by any means, electronic, mechanical or photocopying, recording, or otherwise without the prior permission of the publisher.

Published by

Charles University in Prague, Center for Economic Research and Graduate Education (CERGE) and

Economics Institute ASCR, v. v. i. (EI)

CERGE-El, Politických vězňů 7, 11121 Prague 1, tel.: +420 224005 153, Czech Republic.

Printed by CERGE-EI, Prague

Subscription: CERGE-EI homepage: http://www.cerge-ei.cz

Editors: Directors of CERGE and EI

Managing editors: Deputy Directors for Research of CERGE and EI

ISSN 1211-3298

ISBN 978-80-7343-164-8 (Univerzita Karlova. Centrum pro ekonomický výzkum

a doktorské studium)

ISBN 978-80-7344-153-1 (Národohospodářský ústav AV ČR, v. v. i.) 
CERGE-EI

P.O.BOX 882

Politických vězňů 7

11121 Praha 1

Czech Republic http://www.cerge-ei.cz 